Jurnal Teknologi Informasi dan Ilmu Komputer (JTIIK)

Vol. 3, No. 2, Juni 2016, hlm. 103-109

\title{
OPTIMASI KOMPOSISI MAKANAN UNTUK ATLET ENDURANCE MENGGUNAKAN METODE PARTICLE SWARM OPTIMIZATION
}

\author{
Zilfikri Yulfiandi Rachmat ${ }^{1}$, Dian Eka Ratnawati ${ }^{2}$, Achmad Arwan ${ }^{3}$ \\ 1,2,3 Teknik Informatika, Fakultas Ilmu Komputer, Universitas Brawijaya ${ }^{2}$ Afiliasi Penulis Dua \\ Email: ${ }^{1}$ zilfikriyr@gmail.com, ${ }^{2}$ dian_ilkom@ub.ac.id, ${ }^{3}$ arwan@ub.ac.id
}

(Naskah masuk: 20 Mei 2016, diterima untuk diterbitkan: 20 Juni 2016)

\begin{abstract}
Abstrak
Olahraga adalah aktivitas yang tidak terpisahkan dari kehidupan sehari-hari sebagian besar masyarakat karena dapat menjaga kesehatan tubuh. Salah satu jenis dari olahraga adalah olahraga Endurance (ketahanan). Olahraga ini di tiap tahunnya mengalami peningkatan jumlah atlet yang berpartisipasi. Saat perlombaan atau turnamen olahraga, selain latihan yang rutin, komposisi makanan yang tepat adalah salah satu faktor yang menunjang performa atlet agar menjadi lebih baik. Pada penelitian ini menggunakan metode PSO (Particle Swarm Optimization) untuk menentukan kombinasi bahan makanan untuk memenuhi kebutuhan gizi atlet olahraga endurance dalam sehari. Total bahan makanan yang digunakan sebanyak 125 bahan dan tiap makanan memiliki kandungan gizi berupa protein, lemak, dan karbohidrat. Untuk setiap partikel dalam metode PSO mengandung 14 bahan makanan dengan direpresentasikan nomor bahan makanan dari tabel database bahan makanan. Dari hasil pengujian parameter metode PSO pada penelitian ini diperoleh ukuran populasi terbaik sebesar 200 partikel, jumlah iterasi terbaik sebanyak 80, dan kombinasi nilai $\mathrm{C} 1$ dan $\mathrm{C} 2$ adalah 1 dan 1 . Hasil dari uji coba studi kasus, dapat disimpulkan bahwa sistem dapat memberikan hasil rekomendasi menu makanan yang baik, yaitu yang masih dalam batas tolerasi $\pm 10 \%$ selisih kecukupan kebutuhan gizi untuk atlet olahraga Endurance.
\end{abstract}

Kata Kunci: Particle Swarm Optimization, PSO, Komposisi Makanan, Atlet, Olahraga Endurance.

\begin{abstract}
Sport is an activity that can't be separated from daily life because their benefits for health. Endurance sport is one of the sport's variety. Nowadays, People that interested in Endurance sport are increasing. Thus, when the tournament season or competition are coming, the food compositions for diet are one of factors that had a necessary role for increasing the performance of an athlete in a daily occasion. This research used 125 of foods and each of it contained different proportion of nutritions included protein, fat, and carbohydrate. For each particles in PSO methode contained 14 different food ingredients that will be represented with index based on the database of this research. The giving result of PSO method's testing that has been conducted are 200 particles for best population, 80 iterations, and the combination for $C 1$ and $C 2$ is 1 and 1 . From those result can be concluded that the system of this research able to give a fitting recommendation of food composition, by using the $\pm 10 \%$ of tolerance limit of nutrition difference between athlete's nutrition needs and nutrition recommendation from the system.
\end{abstract}

Keywords: Particle Swarm Optimization, PSO, Food Composition, Athlete, Endurance Sport.

\section{PENDAHULUAN}

\subsection{Latar Belakang}

Makanan adalah sumber utama manusia untuk mendapatkan energi dan juga kebutuhan akan gizi untuk berkembang menjadi lebih baik. Ada banyak macam kandungan yang diperlukan manusia yang bisa diperoleh dari makanan seperti karbohidrat, vitamin, lemak, protein dan sebagainya. Sumber makanan pun juga banyak seperti buah-buahan, umbi-umbian, sayuran-sayuran, dan atau yang berasal dari hewan atau biasa disebut hewani.

Kandungan tiap jenis makanan pun tentunya berbeda-beda, oleh karena itu pentingnya mengatur apa yang kita makan agar memenuhi kebutuhan kalori atau gizi bisa tercakupi. Selain mengatur komposisi makanan, perlu diperhatikan juga porsi makanan yang akan dikonsumsi, diusahakan agar tidak terlalu banyak atau terlalu sedikit dari yang seharusnya dibutuhkan. Dengan kandungan dan porsi yang benar dan cukup inilah yang menjadi sebuah diet yang optimal.

Diet yang optimal ini diperlukan semua orang, khususnya mereka yang merupakan seorang Atlet. Atlet adalah seseorang yang bertanding dalam sebuah perlombaan fisik, Atlet ada yang amatir dan juga yang profesional. Latihan dan perlombaan mewajibkan para Atlet untuk selalu mengatur pola makan, terutama ketika mendekati perlombaan dan ketika lomba itu berlangsung. Rutinitas Atlet secara fisik pada umumnya lebih berat dibandingkan 
mereka yang non-Atlet atau berolahraga hanya di waktu luang.

Parameter untuk diet yang optimal dengan komposisi makanan seringkali menggunakan batasan harga dari makanan tersebut. Harga makanan yang bervariasi dan juga jumlah yang dibutuhkan perlu dalam kuantitas tertentu menjadi pertimbangan untuk selalu mencari harga termurah tapi mendapatkan komposisi makanan yang baik untuk diet yang optimal.

Atlet pun memiliki bervariasi jenis olahraga, mulai dari Atlet lari maraton, renang, bulu tangkis, angkat besi dan lain sebagainya. Olahraga yang ditekuni para Atlet pun memiliki kriteria dan kebutuhan yang berbeda, dan pengkategorian jenis olahraga cenderung berdasarkan pada aspek apa olahraga tersebut sangat dibutuhkan. Endurance adalah aspek olahraga yang menjadi pembahasan sekarang, salah satu komponen dari kebugaran fisik, sehingga sebagian besar Atlet harus memiliki otot yang kuat dan cardiorespiratory (daya tahan jantung dan paru-paru) ditingkat tertentu untuk bisa melakukan olahraga yang Endurance adalah aspek utamanya (Fink, et al., 2011). Contoh Atlet Endurance ini adalah pelari, pesepeda, perenang dan olahraga yang memerluka stamina untuk jangka waktu tertentu. Kebutuhan gizi Atlet Endurance ini tentu berbeda dengan Atlet Power dan lainnya. Atlet Endurance memerlukan karbohidrat dan lemak cadangan yang bisa bertahan sehingga bisa diolah lebih lama, atau menjadi cadangan energi yang diperlukan untuk penggunaan yang tidak sebentar pula.

Durasi olahraga yang lama inilah yang menyebabkan seorang Atlet memerlukan kalori yang banyak sehingga mereka tidak kehabisan energi ketika bertanding. Komposisi makanan yang benar dan juga porsi yang cukuplah yang menjadi pendukung performa seorang Atlet disamping olahraga yang teratur. Diet dan atau komposisi makanan yang baik juga akan menjadi energi cadangan yang baik.

Banyak metode yang bisa digunakan untuk menghitung atau melakukan optimasi komposisi makanan, salah satunya adalah Particle Swarm Optimization (PSO). PSO adalah sebuah metode dalam bidang Algoritma Evolusi yang diciptakan oleh Kennedy dan Eberhart pada tahun 1995. Algoritma ini terinspirasi oleh sekumpulan hewan, atau biasa disebut swarm, yang sedang mencari makanan, contohnya burung atau ikan. Kawanan hewan ini akan bergerak secara bersamaan dalam suatu daerah untuk mencari letak pasti makanan, ketika salah satu individu menemukan lokasi makanan terdekat maka hewan lainnya akan mengikuti arah hewan yang sudah menemukan makanan tersebut. Jadi, penjelasan singkat tersebut menyatakan bahwa ketika ada hewan yang sudah menemukan makanan, maka hewan tersebutlah yang akan menjadi pusat dari hewan-hewan lainnya, atau dialah yang memiliki nilai fitness terbaik. Nilai fitness adalah nilai yang menjadi bobot untuk menentukan sebuah solusi permasalahan. (Retno Putri, I., 2015)

Berdasarkan uraian tersebut diatas, maka diusulkan sebuah optimasi komposisi makanan untuk atlet Endurance menggunakan metode Particle Swarm Optimization.

\subsection{Rumusan Masalah}

Adapun rumusan masalah yang ada pada penelitian ini berdasarkan latar belakang diatas adalah:

Bagaimana menggunakan parameter Particle Swarm Optimization untuk melakukan optimasi menu makanan pada Atlet olahraga Endurance?

Apakah dengan menggunakan metode Particle Swarm Optimization sistem mampu memberikan komposisi makanan yang baik?

\subsection{Batasan Masalah}

Adapun beberapa batasan masalah di penulisan ini adalah:

1. Data Atlet dan komposisi makanan yang ada, adalah hasil secara umum dan tidak khusus atau spesifik, sehingga tentu saja akan ada beberapa perbedaan pada kondisi riil yang akan diabaikan.

2. Penelitian ini hanya mengoptimasi komposisi makanan dan bukan dalam bentuk menu makanan siap saji.

3. Atlet olahraga Endurance dalam penelitian ini diasumsikan tidak memiliki alergi terhadap makanan tertentu.

4. Kandungan gizi yang diperhitungan hanya karbohidrat, protein, dan lemak.

\section{KAJIAN PUSTAKA}

\subsection{Atlet Olahraga Endurance}

Atlet Endurance adalah Atlet yang sedang melakukan aktifitas olahraga Endurance berkisar antara 30 menit hingga 4 jam. Untuk mereka yang beraktifitas lebih dari 4 jam disebut dengan Atlet Ultra-Endurance. Dikarenakan durasi dan sifat kontinyu dari olahraga ini kebutuhan mereka akan kalori tidak hanya ketika kompetisi sedang berlangsung, namun ketika sedang latihan pula. Sekitar 8.000 Kalori diperlukan tiap hari untuk Atlet ini ketika mereka melakukan rutinitasnya. Kebutuhan yang besar ini lah yang membuat seorang Atlet olahraga Endurance tidak bisa hanya memilih makanan begitu saja, namun komposisi dan waktu makan juga sangatlah krusial bagi kondisi mereka. (Fink, et al., 2011). Beberapa contoh atlet yang termasuk dalam kategori atlet olahraga endurance 
adalah atlet olahraga lari maraton, sepeda, renang, tenis, dan bulutangkis.

\subsection{Asupan Energi untuk Atlet Olahraga Endurance}

Energi adalah sumber utama tubuh sebagai asupan untuk proses metabolisme di tubuh. Satuan yang digunakan dalam menghitung energi adalah kilokalori (kkal) dan kalori (kal), satuan ini biasa digunakan dalam perhitungan REE (Resting Energy Expenditure). Banyaknya energi yang berasal dari asupan makanan harus disesuaikan dengan kebutuhan energi yang digunakan oleh tubuh tiap harinya (Supriasa dalam Suci, 2015).

Menyeimbangkan energi yang diasup dengan energi yang digunakan tiap harinya adalah hal yang harus diperhatikan oleh para Atlet endurance. Lamanya latihan dan juga jarak yang harus ditempuh dalam latihan maupun kompetisi menjadikan kebutuhan akan kalori sangatlah besar. Jika kalori tidak terpenuhi maka dapat mengakibatkan performa olahraga menurun dan memburuk. Persamaan untuk memperkirakan total energy atau REE yang diperlukan oleh Atlet Endurance bisa dilihat pada persamaan 2.1 hingga 2.6 yang didapatkan dari WHO (Fink, et al., 2011)

Laki - laki $(10-18$ tahun $): \operatorname{REE}=(17,5 \times \mathrm{BW})+651$

Laki - laki $(18-30$ tahun $): \operatorname{REE}=(15,3 \times \mathrm{BW})+679$

(2.2)

Laki - laki $(30-60$ tahun $): \operatorname{REE}=(11,6 \times \mathrm{BW})+879$

Perempuan $(10-18$ tahun $): \operatorname{REE}=(12,2 \times \mathrm{BW})+749$

(2.4)

Perempuan $(18-30$ tahun $): \operatorname{REE}=(14,7 \times \mathrm{BW})+496$

Perempuan $(30-60$ tahun $): \mathrm{REE}=(8,7 \times \mathrm{BW})+829$

(2.6)

Setelah mendapatkan nilai REE, selanjutnya menghitung nilai total kebutuhan kalori yang diperlukan.

Total energi : REE $\times$ Faktor aktivitas

Keterangan :

- $\quad$ REE (Resting Energy Expenditure) = Jumlah energi yang dibutuhkan oleh Atlet

- $\quad$ BW $($ Body Weight $)=$ Berat badan Atlet dalam satuan kilogram

- Faktor aktivitas untuk olahraga endurance berkisar antara 1,6-2,4 (Fink, et al., 2011)
Untuk nilai dari faktor aktifitas dijelaskan di tabel 1 .

Tabel 1. Faktor Aktivitas Atlet Olahraga Endurance

\begin{tabular}{|l|l|}
\hline Level Aktivitas & Faktor Aktivitas \\
\hline $\begin{array}{l}\text { Pelaku olahraga secara } \\
\text { umum } \\
\text { (latihan } 10-12 \text { jam tiap } \\
\text { minggu) (Pemula) }\end{array}$ & 1,6 \\
\hline $\begin{array}{l}\text { Atlet amatir } \\
\text { (latihan } 12-20 \text { jam tiap } \\
\text { minggu) }\end{array}$ & 2 \\
\hline $\begin{array}{l}\text { Atlet profesional } \\
\text { (latihan > jam tiap minggu) }\end{array}$ & 2,4 \\
\hline
\end{tabular}

Setelah menghitung asupan kalori yang diperlukan oleh atlet olahraga endurance selanjutnya dapat dihitung kebutuhan gizi atlet. Berdasarkan hasil konsultasi dengan ahli gizi, persentase kebutuhan gizi berupa kabohidrat, protein, dan lemak dari total kebutuhan kalori dapat dilihat pada Tabel 2.

Tabel 2. Kebutuhan Gizi Atlet Olahraga Endurance

\begin{tabular}{|c|c|c|}
\hline Karbohidrat & Protein & Lemak \\
\hline $65 \%$ & $15 \%$ & $20 \%$ \\
\hline
\end{tabular}

\subsection{Particle Swarm Optimization}

Algoritma PSO pertama kali dikenalkan pada tahun 1995 oleh Kennedy dan Eberhart (Dhanasaputra dan Santosa, 2012). Proses dari PSO ini diawali dengan inisialisasi sebuah populasi yang terdiri dari berbagai macam partikel yang akan diinisialisasikan pula secara random, hasil dari proses tersebut adalah memperbaiki partikel, yang sebelumnya sudah dipilih sebagai yang terbaik, untuk beberapa iterasi tertentu. Secara teori PSO memiliki memory untuk menyimpan solusi terbaik yang sudah didapatkan dari hasil pemilihan partikel. Partikel yang ada di PSO juga tidak akan menghilang setelah melakukan proses dalam sebuah iterasi, tapi mereka akan terus a da dan akan terupdate nilai-nilainya. Nilai yang ada pada sebuah partikel di PSO adalah posisi dan kecepatan, yang nantinya akan selalu berubah setiap iterasi atau iteratif.

Algoritma ini bisa diumpakan, bahkan terinspirasi oleh, sebuah tingkah laku sosial sekawanan burung atau ikan yang sedang mencari makanan. Misal, ada sekawanan burung yang sedang mencari makanan di sebuah daerah, tapi kawanan burung tersebut tidak tahu lokasi pasti dari makanan yang ada. Sehingga, tiap partikel tersebut akan terbang dengan jarak tertentu antar partikel agar pencarian makanan di daerah tersebut ditemukan dan ketika salah satu partikel menemukan makanan maka kawanan itu akan terbang dengan burung yang menemukan makanan sebagai pusat arah terbang.(Retno Putri, I., 2015) 
Dari penjelasan tersebut, bisa diumpamakan burung-burung tersebut adalah partikel-partikel yang tiap partikel memiliki memory untuk mengingat posisi dan kecepatan terbang mereka. Untuk setiap pencarian akan menjadi sebuah iterasi, sedangkan partikel yang mengetahui lokasi makanan atau pusatnya akan menjadi nilai fitness terbaik dari iterasi tersebut.

Pada PSO yang akan diimplementasikan pada penelitian ini, suatu partikel atau solusi memiliki tiga vektor dan juga terdapat 2 nilai fitness yang berbeda. Vektor tersebut adalah $X, P$, dan $V$. Vektor $X$ adalah vektor yang menyimpan nilai posisi sebuah partikel ketika sedang melakukan pencarian, $\mathrm{Xi}=(\mathrm{xi} 1, \mathrm{xi} 2, \ldots, \mathrm{xiD})$. Vektor $\mathrm{P}$ adalah vektor yang nantinya akan menyimpan posisi terbaik dari keseluruhan posisi partikel yang ada, $\mathrm{Pi}=($ pi1, pi2, ..., piD). Sedangkan Vektor $\mathrm{V}$ adalah vektor yang berisi gradient atau arah yang menyatakan kemana partikel akan terbang, $\mathrm{Vi}=(\mathrm{vi} 1, \mathrm{vi} 2, \ldots$, viD). Dua fitness yang ada berasal dari Vektor X dan Vektor P sebagai fitness pertama atau Fitness X dan Fitness $\mathrm{P}$ yang berasal dari Vektor P. Dalam perhitungan PSO juga terdapat beberapa variabel yang nantinya akan digunakan, yaitu $r l, r 2, C 1$, dan $C 2$. $r 1$ dan $r 2$ adalah variabel berisikan nilai acak antara 0 dan 1 yang dibangkitkan di setiap iterasi. Sedangkan variabel $C 2$ dan $C 2$ adalah dua nilai yang disebut cognitive dan social acceleration coefficients. (Tri Rahajoeningroem, 2015).

\section{METODOLOGI}

Metodologi penelitian menjelaskan metode yang digunakan serta langkah - langkah yang dilakukan dalam optimasi komposisi makanan untuk atlet olahraga endurance dengan menggunakan algoritma genetika.

\subsection{Data Penelitian}

1. Data bahan makanan yang didapatkan dari data penelitian yang dilakukan oleh Rianawati pada tahun 2015. Data tersebut diperoleh oleh peneliti sebelumnya melalui Tabel Komposisi Makanan Indonesia yang dikeluarkan oleh Departemen Kesehatan RI serta program nutrien survey gizi Universitas Brawijaya.

2. Data responden atlet olahraga endurance yang didapatkan melalui proses wawancara terhadap pelatih salah satu atlet olahraga endurance. Data yang didapatkan dari kuesioner tersebut nantinya akan digunakan dalam proses pengujian sistem.

\subsection{Siklus Penyelesaian Masalah Menggunakan Particle Swarm Optimization}

Berikut adalah tahapan - tahapan pada proses optimasi dengan menggunakan Particle
Swarm Optimization :

1. Inisialisasi parameter awal yang meliputi :

a. Parameter C1 \& C2.

b. Parameter r1 \& r2.

c. Parameter Particle Swarm Optimization.

2. Membangkitkan populasi awal sebanyak populasi yang ditentukan pada proses inisialisasi parameter. Pada proses tersebut, indeks bahan makanan secara acak akan dimasukkan dalam partikel sebanyak 14 bahan makanan. Contoh pembangkitan populasi awal dengan 5 populasi dapat dilihat pada tabel 3 berikut ini:

Tabel 3. Contoh 5 populasi awal

\begin{tabular}{|c|c|c|c|c|c|c|}
\hline \multicolumn{2}{|c|}{} & P1 & P2 & P3 & P4 & P5 \\
\hline \multirow{5}{*}{ Pagi } & PK & 18 & 6 & 20 & 18 & 6 \\
\cline { 2 - 7 } & N & 6 & 15 & 11 & 21 & 22 \\
\cline { 2 - 7 } & S & 7 & 23 & 10 & 24 & 3 \\
\cline { 2 - 7 } & H & 23 & 18 & 11 & 5 & 13 \\
\cline { 2 - 7 } & PL & 20 & 12 & 14 & 20 & 24 \\
\hline \multirow{5}{*}{ Siang } & PK & 13 & 6 & 7 & 22 & 17 \\
\cline { 2 - 7 } & N & 3 & 2 & 6 & 7 & 24 \\
\cline { 2 - 7 } & S & 8 & 19 & 24 & 10 & 16 \\
\cline { 2 - 7 } & H & 6 & 27 & 7 & 20 & 24 \\
\cline { 2 - 7 } & PL & 8 & 23 & 6 & 14 & 10 \\
\hline \multirow{4}{*}{ Malam } & PK & 23 & 5 & 2 & 15 & 3 \\
\cline { 2 - 7 } & N & 9 & 20 & 3 & 5 & 2 \\
\cline { 2 - 7 } & S & 19 & 18 & 8 & 16 & 3 \\
\cline { 2 - 7 } & PL & 16 & 2 & 18 & 13 & 23 \\
\hline
\end{tabular}

3. Melakukan perhitungan fitness untuk tiap partikel. Perhitungan nilai fitness dilakukan untuk mengetahui nilai setiap individu terhadap pelanggaran atau penalti. Semakin besar nilai fitness yang dimiliki oleh suatu individu maka semakin baik solusi yang diberikan oleh partikel tersebut (Nurvenus, 2015). Pada penelitian ini, rumus fitness yang digunakan adalah fitness untuk masalah pencarian nilai minimum. Persamaan dari nilai fitness tersebut dapat dilihat pada Persamaan 3.1 berikut:

$$
\text { Fitness }=10000 /(\text { Penalti }+ \text { Total Harga })
$$

Pada persamaan di atas, konstanta yang digunakan pada nilai fitness adalah 10000 karena rentang harga bahan makanan berkisar antara ribuan hingga belasan ribu. Total penalti terdiri atas penalti kalori, karbohidrat, protein, dan lemak yang merupakan selisih dari kebutuhan gizi atlet dengan kandungan gizi bahan makanan pada satu individu yang akan dikalikan dengan nilai prioritas masing-masing. Total harga merupakan penjumlahan dari seluruh harga bahan makanan pada satu individu dan akan dikalikan dengan nilai 0.5 untuk mengurangi efek dari total harga tersebut.

4. Menentukan pBest. Penentuan pBest dilakukan 
dengan membandingkan fitness partikel yang sudah ada dengan partikel hasil dari Position. Nilai fitness yang dipilih adalah nilai fitness yang terbesar dari semua partikel yang ada dalam 1 iterasi.

5. Menentukan gBest. Penentuan gBest adalah dengan membandingkan semua nilai fitness pBest. Nilai gBest akan diupdate jika ditemukan nilai $p$ Best yang lebih baik dari sebelumnya atau yang terbaik dari keseluruhan nilai pBest yang ada.

6. Melakukan update nilai Velocity. Perhitungan velocity adalah tahap pertama dalam perhitungan Particle Swarm Optimization ditiap iterasi sebelum melakukan kalkulasi Position, velocity merupakan fungsi kecepatan sebuah partikel untuk menentukan kemana posisi selanjutnya yang akan dikalkulasi dalam sebuah partikel. Rumus dari kalkulasi velocity dapat dilihat pada persamaan 3.2 berikut:

$$
\begin{aligned}
& v_{i d}(t+1)=v_{i d}+c_{1} r_{l}\left(p_{i d}(t)-x_{i d}(t)\right)+ \\
& c_{2} r_{2}\left(p_{g d}(t)-x_{g d}(t)\right)
\end{aligned}
$$

7. Melakukan update Position. Menghitung Position adalah kalkulasi untuk menentukan letak posisi indeks makanan yang ada di partikel, untuk melakukan kalkulasi dan update posisi baru adalah dengan menambahkan velocity atau kecepatan yang sudah dihitung untuk tiap partikel dijumlah dengan current position atau posisi sebelumnya, lalu nilai dari posisi tersebut akan dibulatkan. Posisi baru ini nantinya akan menjadi partikel yang akan dibandingkan fitnessnya dengan fitness dari partikel sebelumnya, dan yang terbaik akan menjadi pBest. Persamaan 3.3 menjelaskan rumus tentang update Position

$$
x_{i d}(t+1)=x_{i d}(t)+v_{i d}(t+1)
$$

8. Mengulangi langkah 3-7 sejumlah partikel yang ada.

9. Melakukan iterasi hingga kondisi berhenti tercapai dengan hasil berupa partikel terbaik dari seluruh iterasi atau iterasi.

Flowchart untuk tahapan - tahapan pada Particle Swarm Optimization dapat dilihat pada Gambar 1.

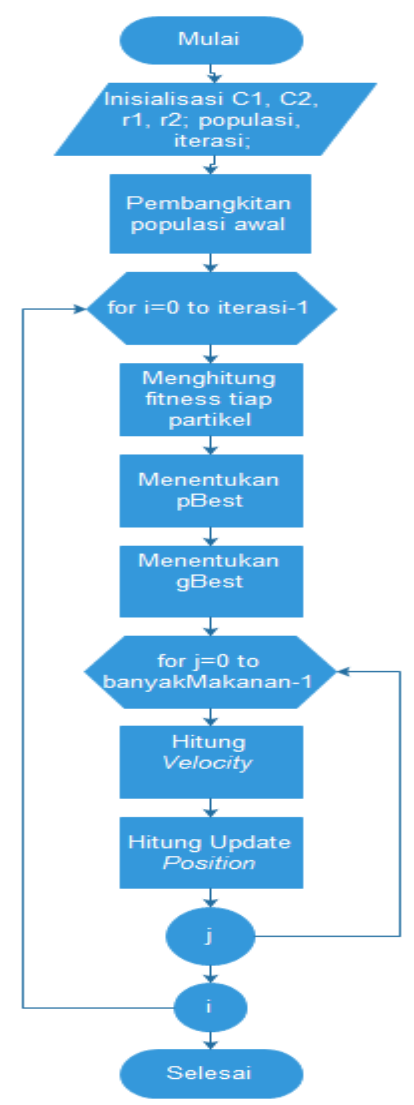

Gambar 1. Flowchart PSO

\section{PENGUJIAN DAN ANALISIS}

Pengujian yang dilakukan terdiri atas uji coba ukuran populasi, uji coba banyaknya iterasi, uji coba kombinasi $C 1$ dan $C 2$, dan uji coba sistem. Data atlet yang digunakan adalah atlet berjenis kelamin laki laki berusia 20 tahun dengan jenis atlet amatir dan berat badan $55 \mathrm{~kg}$. Bahan makanan yang digunakan untuk pengujian adalah 125 data bahan makanan.

\subsection{Hasil dan Analisa Uji Coba Ukuran Populasi}

Uji coba ukuran populasi dilakukan untuk melihat pengaruh ukuran populasi terhadap nilai fitness. Jumlah populasi adalah dari 25 hingga 200 partikel. Banyaknya iterasi yang digunakan dalam uji coba adalah 20 dengan nilai $\mathrm{C} 1=1$ dan nilai $\mathrm{C} 2=1$. Banyak populasi yang digunakan secara berurutan adalah 25, 50, 75, 100, 125, 150, 165, 180, 190, 200. Dari data hasil percobaan dapat dibuat sebuah grafik untuk melihat pengaruh perubahan ukuran populasi terhadap nilai fitness seperti pada Gambar 2.

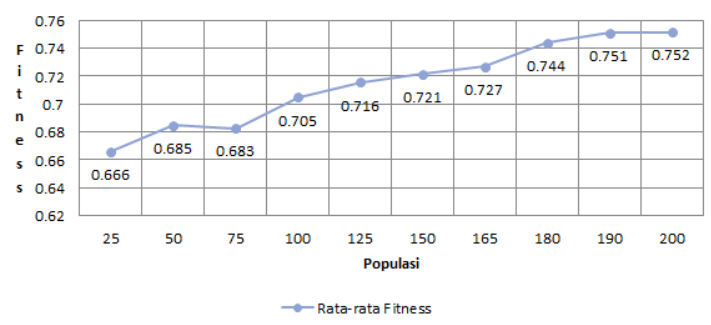

Gambar 2. Hasil Uji Coba Ukuran Populasi 
Dari hasil uji coba banyak populasi nilai fitness terendah ada pada populasi terkecil yaitu 25 dengan nilai rata-rata fitness 0.666208 dan tertinggi ada pada populasi 200 dengan nilai rata-rata fitness 0.75155. Dari gambar 2. bisa disimpulkan bahwa semakin banyak populasi yang ada semakin tinggi nilai fitness didapatkan, meskipun pada populasi ukuran populasi ke-3 terdapat penurunan tapi nilainya tidak signifikan. Peningkatan yang terjadi dikarenakan semakin banyak populasi, maka semakin besar ruang lingkup pencarian dan variasi nilai fitness.

\subsection{Hasil dan Analisa Uji Coba Banyaknya Iterasi}

Uji coba banyaknya iterasi dilakukan untuk melihat pengaruh banyaknya iterasi terhadap nilai fitness yang dihasilkan. Jumlah iterasi yang digunakan dalam penelitian ini adalah kelipatan 10 mulai dari 10 hingga 100 iterasi. Untuk setiap jumlah iterasi dilakukan percobaan sebanyak 10 kali. Dalam uji coba, ukuran populasi yang digunakan adalah hasil terbaik dari pengujian banyak populasi yaitu ukuran populasi 200 dengan $C 1=1$ dan $C 2=$ 1.

Dari data hasil percobaan dapat dibuat sebuah grafik untuk melihat pengaruh perubahan banyaknya iterasi terhadap nilai fitness seperti pada Gambar 3. Rata - rata fitness terendah berada pada iterasi pertama yaitu 10 iterasi dengan nilai rata - rata fitness 0,747836 dan rata - rata fitness tertinggi berada pada iterasi ke- 8 yaitu 80 iterasi dengan rata - rata nilai fitness 0,800163. Berdasarkan grafik pada Gambar 3, nilai rata-rata fitness tidak stabil mulai dari iterasi pertama hingga terakhir, meskipun begitu nilai rata-rata fitnessi antar pengujian tidak memiliki selisih nilai yang signifikan terkecuali fitness rata-rata percobaan ke-8. Bisa disimpulkan bahwa banyaknya iterasi yang dilakukan tidak berpengaruh besar terhadap nilai fitness selama iterasi yang dilakukan tidak terlalu minimalis, hal ini bisa dikarenakan nilai random dari setiap iterasi yang selalu berubah-ubah.

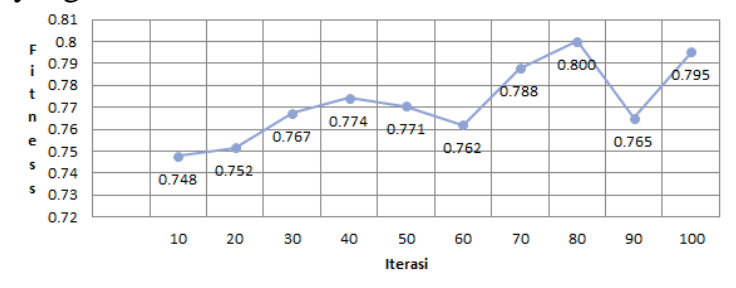

Gambar 3. Hasil Uji Coba Jumlah Generasi

\subsection{Hasil dan Analisa Uji Coba Kombinasi C1 dan $C 2$}

Uji coba kombinasi $C 1$ dan $C 2$ dilakukan untuk mengetahui kombinasi $C 1$ dan $C 2$ yang tepat untuk menghasilkan solusi terbaik. Ukuran populasi yang digunakan berjumlah 200 dengan iterasi sebanyak
80 sesuai dengan hasil terbaik pada uji coba banyak populasi dan uji coba banyaknya iterasi. Pengujian kombinasi $C 1$ dan $C 2$ dilakukan sebanyak 10 kali tiap kombinasi dengan nilai $C 1$ dan $C 2$ secara berurutan adalah $0.5 \& 0.5,1 \& 0.5,0.5 \& 1,1 \& 1$, $1.5 \& 1,1 \& 1.5,1.5 \& 1.5$. Dari data hasil percobaan dapat dibuat sebuah grafik untuk melihat pengaruh kombinasi $\mathrm{C} 1$ dan $\mathrm{C} 2$ terhadap nilai fitness seperti pada Gambar 4.

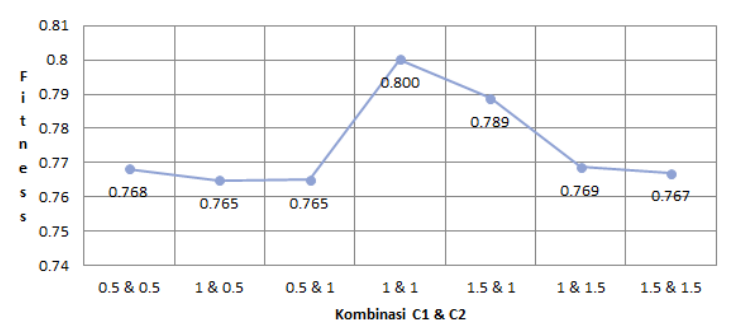

Gambar 4. Hasil Uji Coba Kombinasi $C 1$ dan $C 2$

Berdasarkan grafik pada Gambar 4., kombinasi C1 dan C2 yang digunakan dalam uji coba menghasilkan rata - rata fitness yang terpola. Rata rata fitness terendah didapatkan pada kombinasi $C 1$ $=1$ dan $C 2=0.5$ dengan rata - rata fitness 0,764881 . Untuk rata - rata fitness terbaik didapatkan pada kombinasi $C 1=1$ dan $C 2=1$ dengan rata - rata fitness 0,800163. Pola yang ada pada gambar 4 . menunjukkan ketika nilai kombinasi tersebut mendekati 2 dengan nilai masing-masing 1 maka nilai fitness menjadi lebih tinggi. Sedangkan nilai rata-rata fitness sebagian besar tidak memiliki selisih nilai yang signifikan dibandingan satu dengan yang lainnya, terkecuali nilai fitness yang tertinggi.

\subsection{Hasil dan Analisa Uji Coba Sistem}

Uji Coba sistem dilakukan untuk membandingkan nilai gizi dari rekomendasi menu makanan yang dihasilkan oleh sistem dengan kebutuhan gizi atlet yang seharusnya berdasarkan rumus perhitungan kebutuhan gizi atlet olahraga endurance. Batas toleransi nilai gizi yang ditetapkan oleh ahli gizi untuk menu makanan yang direkomendasikan adalah $\pm 10 \%$ dari kebutuhan gizi atlet olahraga endurance. Hasil uji coba sistem dapat dilihat pada Gambar 5.

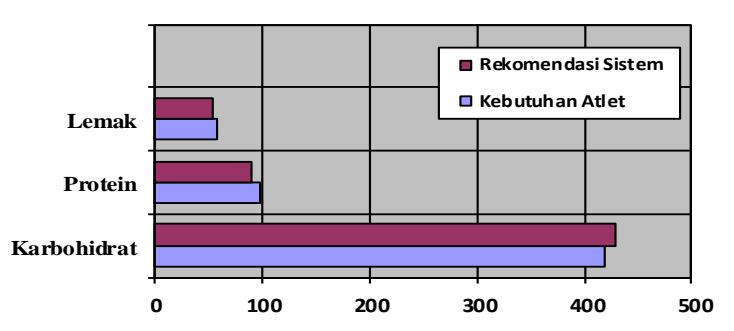

Gambar 4. Hasil Uji Coba Sistem 
Berdasarkan Gambar 5, hasil uji coba sistem memberikan rekomendasi menu makanan dengan 5 komposisi makanan pertama adalah untuk makan pagi, 5 berikutnya untuk makan siang dan 4 terakhir untuk makan malam. Masing - masing makanan pokok memiliki berat sebanyak 180 gram, sumber nabati sebesar 50 gram, sumber hewani sebesar 80 gram, sayuran sebesar 200 gram, dan pelengkap sebesar 150 gram.

Untuk data nilai kebutuhan gizi atlet dan nilai gizi menu makanan yang direkomendasikan oleh sistem dapat dilihat pada Tabel 4.

Tabel 4. Hasil Pemenuhan Gizi dari Sistem

\begin{tabular}{|l|r|c|c|r|}
\hline & $\begin{array}{c}\text { Kalori } \\
\text { (Kal) }\end{array}$ & $\begin{array}{c}\text { Karbohi } \\
\text { drat } \\
\text { (gram) }\end{array}$ & $\begin{array}{c}\text { Protein } \\
\text { (gram) }\end{array}$ & $\begin{array}{c}\text { Lemak } \\
\text { (gram) }\end{array}$ \\
\hline $\begin{array}{l}\text { Kebutuhan } \\
\text { gizi atlet }\end{array}$ & $\begin{array}{r}2581.6 \\
0\end{array}$ & 419.51 & 96.81 & 57.36 \\
\hline $\begin{array}{l}\text { Hasil } \\
\text { rekomenda } \\
\text { si sistem }\end{array}$ & 2425.6 & 428.29 & 88.69 & 54 \\
\hline $\begin{array}{l}\% \text { Selisih } \\
\text { nilai gizi }\end{array}$ & $\begin{array}{c}6.04 \\
\%\end{array}$ & $2.09 \%$ & $5.87 \%$ & $8.37 \%$ \\
\hline
\end{tabular}

Berdasarkan Tabel 4, Nilai selisih dari kebutuhan kalori dan rekomendasi sistem adalah $6.04 \%$, karbohidrat $2.09 \%$, Protein $5.87 \%$, dan Lemak 8.37 $\%$. Dari hasil pengujian tersebut dapat disimpulkan bahwa nilai gizi dari menu makanan yang direkomendasikan oleh sistem masih dalam batas toleransi yang ditetapkan oleh ahli gizi yaitu $\pm 10 \%$ dari kebutuhan gizi atlet olahraga endurance.

\section{PENUTUP}

\subsection{Kesimpulan}

Berdasarkan pengujian dan analisi pada penelitian skripsi berjudul "Optimasi Komposisi Makanan untuk Atlet Endurance Menggunakan Metode Particle Swarm Optimization" maka menghasilkan beberapa kesimpulan sebagai berikut:

1. Hasil terbaik dari pengujian parameter metode Particle Swarm Optimization pada uji coba populasi, uji coba iterasi, dan uji coba kombinasi C1 \& C2 yaitu 200 populasi, 80 iterasi, dan $1 \& 1$. Nilai-nilai tersebut dapat digunakan pada parameter metode Particle Swarm Optimization untuk menyelesaikan permasalahan optimasi komposisi makanan.

2. Hasil dari pengujian sistem pada kasus 1 hingga kasus 4, mampu menyelesaikan masalah dan menunjukkan sistem dapat memberikan rekomendasi makanan dengan baik, dikarenakan selisih untuk tiap kandungan dan kalori antara kebutuhan gizi atlet olahraga endurance dan gizi rekomendasi memiliki selisih tidak melebihi batas toleransi yaitu $\pm 10 \%$.

\subsection{Saran}

Saran untuk pengembangan lebih lanjut dari penelitian skripsi ini adalah :

1. Menggukanan nilai parameter yang lebih beragam pada pengujian parameter metode Particle Swarm Optimization.

2. Menggunakan data uji kasus untuk setiap kategori level atlet.

3. Mencoba menggunakan rumus fitness dan prioritas yang lebih tepat dan atau lebih baik.

4. Menambahkan jumlah makanan agar lebih bervariasi dan lebih luas ruang cakup pencarian komposisi makanan.

5. Menggunakan prioritas gizi bahan makanan dengan nilai yang berbeda.

\section{DAFTAR PUSTAKA}

Fink, HH, Milkesky, AE \& Burgoon, LA . 2011. Practical Application in Sport Nutrition Third Edition. Burlington : Jones \& Bartlett Learning.

Fister, Ljubic, Karin, dkk. 2014. Towards Automatic Food Prediction During Endurance Sport Competitions. Slovenia : Faculty of Electrical Engineering and Computer Science.

Heather H.F, Alan E. M., Lisa A. B., 2013. Practical Applications in Sports Nutrition. $3^{\text {rd }}$ ed. Jones \& Bartlett Learning

Nurvenus Karid, 2015. Penerapan Algoritma Genetikan untuk Optimasi Asupan Gizi Pasien Diet Khusus dengan Biaya Minimal. $\mathrm{S} 1$. Universitas Brawijaya.

Retno Putri, I., 2015. Optimasi Metode Adaptive Fuzzy K-Nearest Neighbor dengan Particle Swarm Optimization untuk Klasifikasi Status Sosial Ekonomi Keluarga. S1. Universitas Brawijaya.

Suci, WW, Mahmudy, WF \& Putri, RRM. 2015. Optimasi biaya pemenuhan gizi dan nutrisi pada manusia lanjut usia menggunakan algoritma genetika. DORO: Repository Jurnal Mahasiswa PTIIK Universitas Brawijaya, vol. 5, no. 17.

Rahajoeningroem T., Aria M.. Studi Komparasi Algoritma Particle Swarm Optimization Pada Aplikasi Filter Adaptive Noise Cancellation. Universitas Komputer Indonesia. 